\title{
Perilaku Keuangan Pada Pelaku UMKM Kelurahan Cinere, Depok
}

\section{Yosua Triawan Harahap ${ }^{1)}$, Alfida Aziz'), Dewi Cahyani. P) Fakultas Ekonomi dan Bisnis, Universitas Pembangunan NasionalVeteran Jakarta}

Email: yosuaharahap@gmail.com, ${ }^{2}$ alfidaaziz61@gmail.com, ${ }^{3}$ dewichepe@upnvj.ac.id

\section{ABSTRACT}

This research is a quantitative study aimed at knowing the financial literacy, financial attitude, and locus aof control to the financial behavior of SMES in Cinere village. This research uses the SME actors in Cinere village as a population of 30 MSMES. The sample collection is done using a saturated sample means all populations as a sample, so selected 30 respondents from a registered population. Data collected by spreading questionnaires. Data analysis testing is a validity test and reusability test as well as hypothesized analysis in this study using the analysis of PLS (Partial Least Square) with the program smartPLS version 3.0 and a signification rate of $5 \%(0.05)$. The results of this study indicated that (1) Financial literacy has no significant effect on financial behavior, (2) Financial attitudes have significant effect on financial behavior, (3) Locus of control significant effect on financial behavior.

Keywords: financial literacy, financial attitude, Locus of Control, Financial behavior.

\section{PENDAHULUAN}

Usaha Mikro Kecil dan Menengah (UMKM) adalah salah satu bagian penting dari perekonomian suatu Negara atau daerah, begitu juga dengan Indonesia. UMKM ini sangat memiliki peranan penting dalam lajunya perekonomian masyarakat. Dengan UMKM ini, menciptakan lapangan kerja baru sehingga akan mengurangi tingkat pengangguran. Saat ini jumlah pelaku UMKM Depok tahun 2019 sekitar 2.385 orang. Keberadaan mereka memiliki kontribusi yang besar dalam membangun Kota Depok, seperti mengurangi angka pengangguran.

Siksa Nirmala menuliskan pada tahun 2019 (pikiran rakyat.com) Kepala OJK Regional 2 Jabar Triana Gunawan mengatakan Tingkat literasi dan inklusi keuangan Jawa Barat menunjukkan peningkatan dan mencapai target yang ditetapkan. Berdasarkan hasil survey yang dilakukan oleh Otoritas Jasa Keuangann (OJK) tingkat inklusi Jabar $88,48 \%$ meningkat dari survei pada 2016 yang tercatat $71,4 \%$. Sedangkan untuk tingkat literasi $37,43 \%$ meningkat dari survei pada tahun 2016 yang tercatat $33 \%$ dari target tingkat inklusi 75\% dan literasi keuangan sebesar 35\% di akhir tahun 2019 telah tercapai. Akan tetapi bahwa tingkat literasi keuangan Provinsi Jawa Barat memiliki tingkat literasi keuangan yang tinggi dan telah melewati dari target literasi yang di berikan OJK. Namun hal tersebut belum membuktikan bahwa masyarakat sudah memiliki literasi keuangan yang tinggi pula. Tri Nurul Wulan Dewi sebagai Pemilik Perusahaan Audit PT. Moeswel Abadi Konsultan menyatakan bahwa banyak para pelaku UMKM depok yang jago dalam berinovasi tapi masih lemah dari sisi pembukuan keuangan serta banyak pelaku bisnis pemula yang sering melupakan catatan keuangan bisnis yang sedang mereka jalankan karena pelaku UMKM depok tidakumemiliki catatan keuangani yang terorganisir sesuait dengan standar akuntansi, bisa menyebabkan kerugian. Pasalnya, biaya operasional dan biaya lainnya bisa tercampur dan luput dari pencatatan. Akibatnya laba atau rugi tidak bisa diperhitungkan dan rentan terjadi kekeliruan data finansial.

\section{5}

Submitted: AGUSTUS 2020

Accepted: NOVEMBER 2020

\section{JIMKES}

Jurnal Ilmiah Manajemen Kesatuan Vol. 8 No. 3, 2020 pp. $225-238$ IBI Kesatuan ISSN $2337-7860$ E-ISSN $2721-169 \mathrm{X}$ 
Financial Behavior and Small Medium Enterprises
Permasalahan yang dihadapi oleh UMKM adalah kurangnya literasi keuangan,sikap keuangan dan locus of control. Anggraenin (2015) mengatakan literasi keuangan mempengaruhi cara berpikir seseorang terhadap kondisi keuangan serta mempengaruhi pengambilan keputusan yang strategis dalam hal keuangan dan pengelolaan yang lebih baik bagi pemilik usaha. Adanya pengaruh positif literasi keuangan terhadap perilaku keuangan juga sesuai dengan hasil penelitian dari Ari Susanti (2017). Berbeda halnya dengan penelitian yang telah dilakukannoleh Kholilahh dan Iramanii (2013) yang menyatakan bahwa financial knowledge memiliki pengaruh negatif terhadap financial manajemen behavior.

Menurut Rajna et al(2011) financial attitude merupakan penilaian, pendapat, maupun keadaan pikiran seseorang terhadap keuangan yang diterapkan ke dalam sikapnya. Ketika individu terobsesi terhadap uang, maka individu akan berfikir bagaimana memperoleh uang dan bagaimana penggunaan uang yang dimiliki. adanya pengaruh positif financial attitude terhadap financial management behavior juga sesuai dengan hasil penelitian dari Amanah et al.(2016.). Berbeda halnya dengan penelitian yang telah dilakukan olehRajna et al. (2011) yang menyatakan bahwa financial attiude memiliki pengaruh negatif terhadap perilaku keuangan praktisi kesehatan di Malaysia.

Locus of control adalah cara pandang seseorang terhadap suatu peristiwa apakah seseorang dapat atau tidak dapat mengendalikan peristiwa yang terjadi padanya.Berdasarkan penelitianyang dilakukan Jubaedah (2017.) bahwa variabel Lokus Pengendalianberpengaruhsignifikan positif terhadap Perilaku Keuangan Sesuai dengan penelitian Nur Laila (2018). Akan tetapi berbeda dengan penelitian yang dilakukan oleh Ida dan Dwinta (2010) yang menyatakan bahwa locus of control tidak memiliki pengaruh terhadap financial behavior.

Berdasarkan hasil di atas maka perilaku keuangan dapat dipengaruhi oleh literasi keuangan, sikap keuangan, dan locus of control. Maka perumusan masalahnya adalah untuk mengetahui dan menganalisis apakah terdapat pengaruh dari literasi keuangan, sikap keuangan, dan locus of control terhadap perilaku keuangan.

\section{METODE PENELITIAN \\ Populasi}

Populasi yang digunakan dalam penelitian ini adalah seluruh Pelaku Usaha Mikro, Kecil dan Menengah di Kelurahan Cinere, Depok yang berjumlah 30 UMKM.

\section{Sampel}

Teknik sampel yang di gunakan adalah teknik Sampel Jenuh (Sugiyono (2016, hlm.156) yang merupakan teknik penentuan sampel apabila semua anggota populasi digunakan sebagai sampel karena jumlah populasi relatif kecil. Berdasarkan data yang di peroleh kantor Kecamatan Cinere yaitu 48 UMKM akan tetapi yang dijadikan objek penelitian adalah Kelurahan Cinere maka populasi yang telah diketahui bahwa jumlah UMKM di kelurahan Cinere 30 dan yang dijadikan sampel penelitian adalah UMKM yang berada di kelurahan Cinere yang memiliki jumlah UMKM sekitar 30.

\section{Teknik Pengumpulan Data}

Jenis data yang digunakan adalah data primer dengan Teknik pengumpulan data menggunakan kuesionerdan pengumpulan data dengan membagikan 30 kuesioner kepada pelaku UMKM di Kelurahan Cinere, Depok. Skala yang digunakan adalah skala likert.

Tabel 1. Skala Likert

\begin{tabular}{|c|c|c|}
\hline Pernyataan & Pengertian & Skor \\
\hline SS & Sangat Setuju & 5 \\
\hline S & Setuju & 4 \\
\hline R & Ragu-Ragu & 3 \\
\hline TS & Tidak Setuju & 2 \\
\hline STS & Sangat Tidak Setuju & 1 \\
\hline
\end{tabular}

Sumber: Sugiyono (2016, hlm.169) 
Teknik Analisa Data

Teknik analisa yang digunakan adalah analisis data deskriptif dan analisis PLS.

\section{Analisis Data Deskriptif}

Ferdinan (2014, hlm.229) Analisiis statistik deskriptif diigunakan untuk memberikan gambaran attau deskripsi empiris atas data yang dikumpulkan dalam penelitian. Salah satunya adalah angka indeks yang merupakan alat ukur untuk mendapatkan gambaran mengenai derajat persepsi responden atas variabel yang akan diteliti, sebuah angka indeks dapat dikembangkan. Analisa inii diilakukan untuk mendapatkan gambaran deskriptiif responden mengenai variabel-variiabel yang digunakan dalam penelitian ini. Persepsi responden tersebut digambarkan menggunakan teknik skoring. Teknik skoring yang digunakan adalah dari peringkat 1-5.

Tabel 2. Interpretasi Nilai Presentase Responden

\begin{tabular}{|c|c|}
\hline Nilai indeks. & Interprestasi \\
\hline $6-13$ & Rendah \\
\hline $14-21$ & Sedang \\
\hline $22-30$ & Tinggi \\
\hline
\end{tabular}

Sumber : Ferdinand (2011)

\section{Partial Least Square (PLS)}

Data yang diperoleh dari hasil penelitian diolah menggunakan teknik analisis data yaitu Partial Lest Square (PLS). Menurut Ghozali (2014, hlm.7) menjelaskan Partial Least Square (PLS) merupakan metode analisis yang power full oleh karena tidak didasarkan banyak asumsi, data tidak harus berdistribusi normal multivariate (indicator dengan skala kategori, ordinal sampai rasio dapat digunakan pada model yang sama), sampel tidak harus besar, dan dapat digunakan untuk menjelaskan ada atau tidaknya hubungan antara variabel laten (tak terukur langsung).

\section{Langkah-Langkah PLS}

\begin{tabular}{|c|}
\hline Merancang Model Struktural (Inner Model) \\
\hline Merancang Model Pengukuran (Outer Model) \\
\hline Mengkontruksi Diagram Jalur \\
\hline $\begin{array}{l}\text { Konversi Diagram Jalur ke Sistem Persamaan } \\
\text { Evaluasi Goodness of Fit Estimasi : Koef Jalur }\end{array}$ \\
\hline Estimasi : Koef, Jalur, Loading dan Weight \\
\hline Evaluasi Goodness of Fit \\
\hline Pengujian Hipotesis (Resampling Bootstra \\
\hline
\end{tabular}

Sumber : Noor (2014, hlm.146)

\section{Definisi Operasional}

Gambar 1. Langkah-langkah Analisis PLS

a. Perilaku Keuangan (Y)

Perilaku keuangan adalah kemampuan seseorang dalam mengelola, memperlakukan, dan menggunakan sumber daya keuangan sebagai alat dalam pengambilan keputusan.

b. Literasi Keuangan (X1)

Literasi keuangan yaitu pengetahuan seorang pelaku usaha dalam mengelola keuangan yang dimiliki guna menciptakan kesejahteraan dimasa depan.

c. Sikap Keuangan (X3)

Sikap keuangan merupakan keadaan seseorang mengenai kegiatan menggunakan uang, dimana juga berpengaruh pada cara seseoranggmengatur perilaku keuangannya terhadap pendapatan dan penilaian keuangan. 
Financial Behavior and Small Medium Enterprises d. Locus of Control (X3)

Locus of Control adalah kepercayaan seseorang terhadap dirinya sendiri bahwa dirinya memiliki kendali akan nasib mereka yang terdiri dari kontrol pengendalian internal dan eksternal

\section{Pengukuran Variabel}

Tabel 3. Pengukuran Variabel

\begin{tabular}{|c|c|c|}
\hline Variabel & Indikator Skala & Skala Pengukuran \\
\hline \multirow{4}{*}{$\begin{array}{l}\text { Perilaku Keuangan } \\
\text { (Y) }\end{array}$} & Perencanaan Keuangan & Likert \\
\hline & Penganggaran Keuangan & Likert \\
\hline & Pengelolaan Keuangan & Likert \\
\hline & Penyimpanan Keuangan & Likert \\
\hline \multirow{4}{*}{$\begin{array}{l}\text { Literasi } \\
\left(\mathrm{X}_{1}\right)\end{array}$} & Pengetahuan keuangan dasar & Likert \\
\hline & Pengelolaan Kredit & Likert \\
\hline & Pengelolaan Tabungan dan Investasi & Likert \\
\hline & Manajemen Resiko & Likert \\
\hline \multirow[t]{4}{*}{ Sikap Keuangan $\left(\mathrm{X}_{2}\right)$} & Orientasi terhadap keuangan pribadi & Likert \\
\hline & Filsafat utang & Likert \\
\hline & Keamanan uang & Likert \\
\hline & Menilai keuangan pribadi & Likert \\
\hline \multirow{2}{*}{$\begin{array}{l}\text { Locus of Control } \\
\left(\mathrm{X}_{3}\right)\end{array}$} & Internal locus of control & Likert \\
\hline & Eksternal locus of control & Likert \\
\hline
\end{tabular}

Sumber : Data yang diolah

\section{Kerangka Model Penelitian}

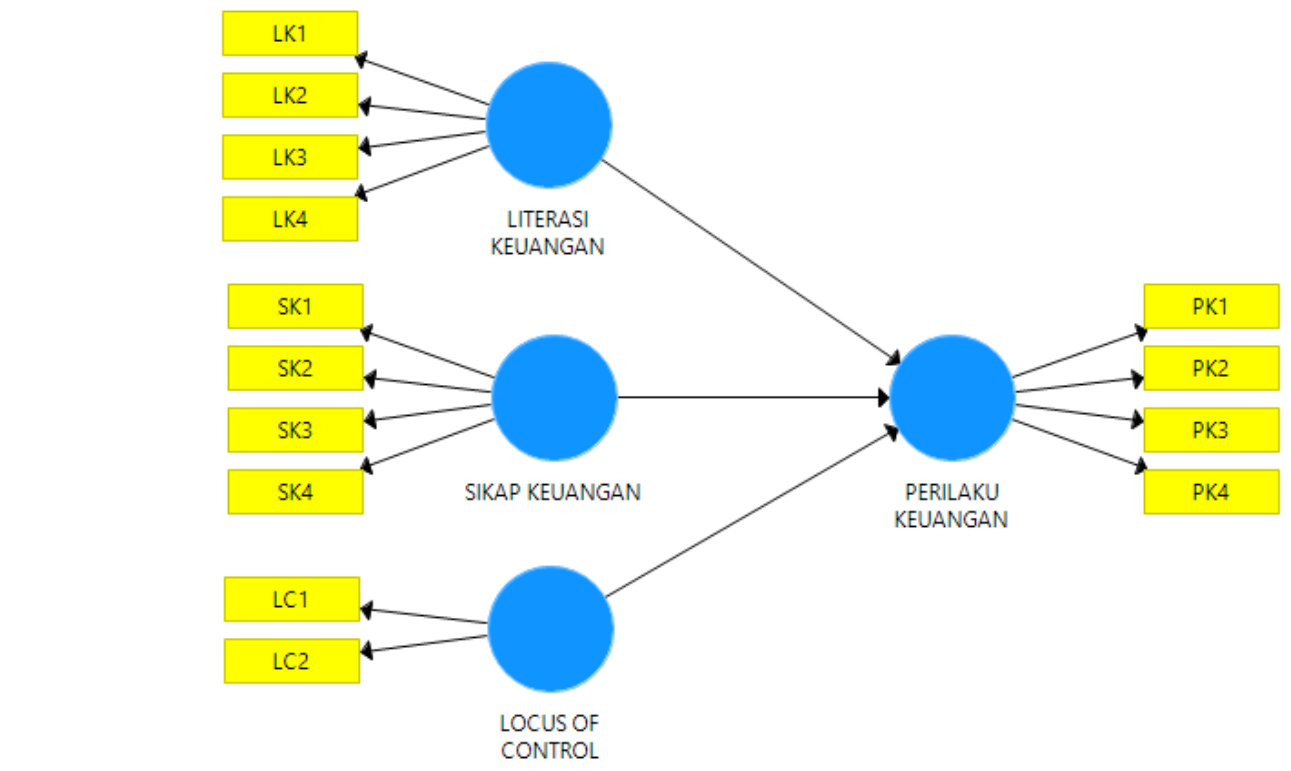

Sumber : Data diolah

Gambar 2. Kerangka Model Penelitian

\section{HASIL DAN PEMBAHASAN \\ Deskripsi Data Responden}

Karakteristik responden menurut jenis kelamin terdapat 14 responden berjenis kelamin laki-laki (47\%) dan 16 responden yang berjenis kelamin perempuan (53\%). Sehingga dapat disumpulkan bahwa UMKM yang berada di Kelurahan Cinere di dominasi oleh perempuan sebagai pelaku usahanya, hal tersebut dikarenakan, banyaknya pelaku 
UMKM ingin menambah pendapatan bukan hanya dari pasangan dan banyak yang berjenis kelamin laki-laki bekerja di sebuah perusahaan atau bekerja diluar desa, sehingga yang mendominasi adalah para pelaku UMKM yang berjenis kelamin perempuan. Karakteristik responden menurut usia terdapat 6 responden : $0 \%$ dengan usia $<19$ tahun, usia 20-25 sebanyak $14 \%$, usia 26-30 terdiri dari $3 \%$, usia $31-40$ berjumlah $33 \%$, usia 41-50 berjumlah $33 \%$ dan usia $50>$ berjumlah $17 \%$. Data menunjukan bahwa yang mendominasi pelaku UMKM kelurahan cinere adalah responden dengan usia 31- 40 tahun dan 41- 50 tahun.

Karakteristik menurut Pendidikan terakhir terdapat 30responden dengan pendidikan terakhir SD/SMP sebesar $10 \%$, untuk pendidikan terakhir SMA/ SMK sebesar $60 \%$, responden dengan pendidikan terakhir S1/S2/S3 sebesar $23 \%$, responden yang dengan pendidikan lainnya yaitu D3 sebesar $7 \%$. Data tersebut menunjukan bahwa yang mendominasi menjadi pelaku UMKM kelurahan cinere adalah responden dengan pendidikan terakhir SMA/ SMK sebesar $60 \%$ maka banyak pelaku UMKM lebih ingin membuka usaha dari pada berkerja di kantoran karena tingkat pendidikan yang rendah.

\section{Analisis Data Deskriptif}

Berikut merupakan hasil dari perhitungan indeks jawaban yang diberikan oleh responden mengenai tanggapan mengenai butir-butir pertanyaan yang telah diajukan melalui kuesioner penelitian :

a. Analisis Indeks Jawaban Responden Terhadap Variabel Literasi Keuangan

Tabel 4. Hasil Jawaban Responden Terhadap Variabel Literasi Keuangan

\begin{tabular}{|c|c|c|c|c|c|c|c|c|c|c|c|}
\hline \multirow[t]{2}{*}{ Literasi Keuangan (X1) } & \multicolumn{2}{|c|}{1} & \multicolumn{2}{|c|}{2} & \multicolumn{2}{|c|}{3} & \multicolumn{2}{|c|}{4} & \multicolumn{2}{|c|}{5} & \multirow[b]{2}{*}{ Indeks } \\
\hline & $\mathrm{F}$ & $\%$ & $\mathrm{~F}$ & $\%$ & $\mathrm{~F}$ & $\%$ & $\mathrm{~F}$ & $\%$ & $\mathrm{~F}$ & $\%$ & \\
\hline LK.1 & 0 & 0 & 0 & 0 & 1 & 3 & 20 & 67 & 9 & 30 & 26 \\
\hline LK. 2 & 0 & 0 & 1 & 3 & 9 & 30 & 9 & 30 & 11 & 37 & 24 \\
\hline LK. 3 & 7 & 23 & 3 & 10 & 12 & 40 & 5 & 17 & 3 & 10 & 17 \\
\hline LK.4 & 0 & 0 & 1 & 3 & 11 & 37 & 5 & 17 & 13 & 43 & 24 \\
\hline LK.5 & 0 & 0 & 0 & 0 & 4 & 13 & 13 & 43 & 13 & 43 & 26 \\
\hline LK.6 & 0 & 0 & 3 & 10 & 7 & 23 & 14 & 47 & 6 & 20 & 23 \\
\hline LK.7 & 1 & 3 & 3 & 10 & 11 & 37 & 9 & 30 & 6 & 20 & 21 \\
\hline LK. 8 & 1 & 3 & 5 & 17 & 10 & 33 & 9 & 30 & 5 & 17 & 20 \\
\hline ata - Rata Total Indeks & 1 & 4 & 2 & 7 & 8 & 27 & 11 & 35 & 8 & 28 & 23 \\
\hline
\end{tabular}

\section{Sumber : Data diolah}

Berdasarkan tabel di atas skor paling tinggi terdapat pada skor 4 yaitu 35\% yang berarti banyak responden yang setuju menjawab angka 4 yaitu setuju dengan butir pertanyaan yang diajukan, ini memberi penjelasan bahwa responden memiliki literasi keuangan yang tinggi khususnya mengenai pengetahuan keuangan dasar, pengelolaan kredit, pengelolaan tabungan dan investasi dan manajemen resiko. skor 5 sebanyak $28 \%$ yang berarti responden yang mengetahui tentang literasi keuangan sangat tinggi. Untuk skor 3 sebanyak $27 \%$ yang berarti masih cukup banyak orang yang cukup setuju dengan literasi keuangan dan menganggap bahwa literasi keuangan cukup penting, Skor 2 memiliki persetase $7 \%$ yang berarti banyak responden yang tidak setuju dengan pertanyaan yanng diiajukan, dalam hal ini responden memiliki literasi keuangan yang rendah. skor 1 sebanyak $4 \%$ yang berarti responden yang mengetahui tentang literasi keuangan masih rendah dibanding dengan yang mengetahui literasi keuangan. Hal ini harus ditingkatkan oleh dinas UMKM setempat agar literasi keuangan para pelaku UMKM dapat meningkat dan usaha yang dijalani pun dapat berkembang. Kesimpulannya untuk jumlah skor yang paling banyak adalah skor 4 yaitu 35\% yang berarti literasi keuangan para pelaku keuangan tinggi khususnya dalam hal pengetahuan keuangan dasar, pengelolaan kredit, pengelolaan tabungan dan investasi dan manajemen resiko.

Berdasarkan tabel di atas untuk analisis variabel literasi keuangan terdapat nilai tertinggi sampai terendah pada butir pertanyaan 1 sampai 8 . Nilai tertinggi berada pada LK1 yaitu $26 \%$ yang pertanyaannya adalah mengenai apakah para pelaku UMKM
Financial Behavior and Small Medium

Enterprises

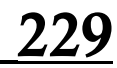


Financial Behavior and Small Medium Enterprises mengetahui cara mengelola keuangan yang baik dan bijaksana, karena banyak pelaku usaha yang menjawab skor 5 yaitu sebesar $30 \%$ dan yang tidak percaya sebesar $0 \%$. LK3 memiliki rata-rata $17 \%$ atau rata-rata terendah dari 8 butir pertanyaan, pertanyaan yang diajukan adalah apakah para pelaku usaha memiliki pengetehauan yang cukup untuk faktor kelayakan kredit dan jawaban yang paling banyak terdapat pada skor 3 yaitu $40 \%$ yang berarti banyak pelaku usaha yang cukup mengetahui tentang factor kelayakan kredit. Rata-rata skor indeks yang dihasilkan dari tabel diatas adalah $23 \%$ untuk variabel literasi keuangan yang dapat dikategorikan ke dalam nilai tinggi.

b. Analisis Indeks Jawaban Responden Terhadap Variabel Sikap Keuangan

230

\begin{tabular}{lcccccccccccc} 
Sikap Keuangan (X2) & \multicolumn{1}{c}{1} & \multicolumn{1}{c}{2} & \multicolumn{1}{c}{3} & \multicolumn{7}{c}{5} \\
SK.1 & $\mathrm{F}$ & $\%$ & $\mathrm{~F}$ & $\%$ & $\mathrm{~F}$ & $\%$ & $\mathrm{~F}$ & $\%$ & $\mathrm{~F}$ & $\%$ & Indeks \\
SK.2 & 0 & 0 & 0 & 0 & 4 & 13 & 16 & 53 & 10 & 33 & 25 \\
SK.3 & 0 & 0 & 0 & 0 & 5 & 17 & 7 & 23 & 18 & 60 & 27 \\
SK.4 & 6 & 20 & 4 & 13 & 8 & 27 & 9 & 30 & 3 & 10 & 18 \\
SK.5 & 10 & 33 & 4 & 13 & 7 & 23 & 6 & 20 & 3 & 10 & 16 \\
SK.6 & 0 & 0 & 0 & 0 & 9 & 30 & 13 & 43 & 8 & 27 & 24 \\
SK.7 & 1 & 3 & 7 & 23 & 5 & 17 & 12 & 40 & 5 & 17 & 21 \\
Ratarata Total Indeks & 1 & 3 & 0 & 0 & 9 & 30 & 14 & 47 & 6 & 20 & 23 \\
Surat: & 9 & 2 & 7 & 7 & 22 & 11 & 37 & 8 & 25 & 22
\end{tabular}

Sumber: Data diolah

Berdasarkan tabel di atas skor paling tinggi terdapat pada skor 4 yaitu 37\% yang berarti banyak responden yang setuju menjawab angka 4 yaitu setuju dengan butir pertanyaan yang diajukan, ini memberi penjelasan bahwa responden memiliki sikap keuangan yang tinggi khususnya mengenai orientasi keuangan pribadi, filsafat utang, keamanan uang, menilai keuangan pribadi. skor 5 sebanyak $25 \%$ yang berarti responden yang mengetahui tentang sikap keuangan sangat tinggi. Untuk skor 3 sebanyak $22 \%$ yang berarti masih cukup banyak orang yang cukup setuju dengan sikap keuangan dan menganggap bahwa sikap keuangan cukup penting, Skor 2 memiliki persetase 7\% yang berarti banyak responden yang tidak setuju dengan pertanyaan yanng diiajukan, dalam hal ini responden memiliki sikap keuangan yang rendah. skor 1 sebanyak $9 \%$ yang berarti responden yang mengetahui tentang sikap keuangan masih rendah dibanding dengan yang mengetahui sikap keuangan khususnya dalam orientasi keuangan pribadi, filsafat utang, keamanan uang, menilai keuangan pribadi. Hal ini harus ditingkatkan oleh dinas UMKM setempat agar sikap keuangan para pelaku UMKM dapat meningkat dan usaha yang di jalani pun dapat berkembang. Kesimpulannya untuk jumlah skor yang paling banyak adalah skor 4 yaitu 37\% yang berarti sikap keuangan para pelaku keuangan tinggi khususnya dalam hal orientasi keuangan pribadi, filsafat utang, keamanan uang, menilai keuangan pribadi.

Berdasarkan tabel diatas untuk variabel sikap keuangan terdapat nilai tertinggi dan terendah pada analisis indeks dari butir pertanyaan 1 sampai 7 terdapat nilai tertinggi sampai terendah. Nilai tertinggi berada pada SK2 yaitu 27\% yang pertanyaannya adalah mengenai apakah para pelaku UMKM memikirkan pentingnya merencanakan keuangan, karena banyak pelaku usaha yang menjawab skor 5 yaitu sebesar $60 \%$ dan yang tidak percaya sebesar $0 \%$. SK4 memiliki skor rata-rata terendah sebesar $16 \%$ yang memiliki pertanyaan apakah para pelaku UMKM membeli bahan baku kepada teman dengan cara berhutang dan jawaban yang paling banyak terdapat pada skor 1 yaitu 33\% yang berarti bahwa para pelaku UMKM tidak ingin membeli bahan baku kepada teman dengan cara berhutang. Rata-rata skor indeks yang dihasilkan dari tabel diatas adalah $22 \%$ untuk variabel sikap keuangan yang dapat dikategorikan ke dalam nilai tinggi.

c. Analisis Indeks Jawaban Responden Terhadap Variabel locus of control

Tabel 4. Hasil Jawaban Responden Terhadap Variabel Locus of Control 


\begin{tabular}{|c|c|c|c|c|c|c|c|c|c|c|c|c|}
\hline \multirow[t]{2}{*}{ Locus of Control (X3) } & \multicolumn{2}{|c|}{1} & \multicolumn{2}{|c|}{2} & \multicolumn{2}{|c|}{3} & \multicolumn{2}{|c|}{4} & \multicolumn{2}{|c|}{5} & & \multirow{2}{*}{$\begin{array}{l}\text { Financial Behavior } \\
\text { and Small Medium }\end{array}$} \\
\hline & $\mathrm{F}$ & $\%$ & $\mathrm{~F}$ & $\%$ & $\mathrm{~F}$ & $\%$ & $\mathrm{~F}$ & $\%$ & $\mathrm{~F}$ & $\%$ & Indeks & \\
\hline LC.1 & 0 & 0 & 1 & 3 & 5 & 17 & 15 & 50 & 9 & 30 & 24 & Enterprises \\
\hline LC. 2 & 0 & 0 & 0 & 0 & 7 & 23 & 15 & 50 & 8 & 27 & 24 & \\
\hline LC. 3 & 2 & 7 & 6 & 20 & 10 & 33 & 10 & 33 & 2 & 7 & 19 & \\
\hline LC. 4 & 1 & 3 & 7 & 23 & 9 & 30 & 9 & 10 & 4 & 13 & 20 & \\
\hline Rata-Rata Total Indeks & 1 & 3 & 4 & 12 & 8 & 26 & 12 & 36 & 6 & 19 & 22 & 23 \\
\hline
\end{tabular}

Sumber: Data diolah

Berdasarkan tabel diatas skor paling tinggi terdapat pada skor 4 yaitu 36\% yang berarti banyak pelaku usaha yang menjawab setuju terhadap butir- butir pertanyaan locus of control, yang berarti para pelaku usaha memiliki locus of control yang tinggi khususnya mengenai locus of control internal (dari dalam diri dan locus of control eksternal (dari luar diri). Skor 3 memiliki persentase sebesar 26\% adalah cukup setuju sedikit yang berargumen netral dalam locus of control. skor 5 yaitu sangat setuju dengan presentase sebesar $19 \%$, hal ini masih cukup banyak para pelaku usaha yang memiliki locus of control internal yaitu percaya bahwa dirinya bisa melakukan apapun karena diri sendiri dan segala kendali berada dalam kendalinya. Skor 2 memiliki presentase sebesar $12 \%$ yang berarti tidak setuju, locus of control masih ada para pelaku usaha yang memiliki locus of control external yang dapat diartikan rendah dan masih belum bisa membuat keputusan sendiri dan masih dikendalikan oleh orang lain. Skor 1 memiliki presentase sebesar 3\% sama seperti skor 2 para pelaku usaha yang berarti banyak pelaku usaha yang menjawab sangat tidak setuju terhadap butir- butir pertanyaan locus of control, karena masih ada pelaku usaha yang memiliki locus of controlexsternal yang berarti tidak percaya diri akan kemampuannya sehingga dalam mengambil keputusan masih di kendalikan orang lain. Kesimpulan untuk locus of control cukup tinggi banyak para pelaku usaha yang memiliki locus of controlinternal yang dapat diartikan tinggi dan bisa membuat keputusan sendiri dan tidak terlalu bergantung kepada orang lain.

Pada tabel diatas terdapat rata-rata indeks untuk setiap butir pertanyaan mengenai locus of control yang terdapat terdapat 4 butir pertanyaan dengan persentase tertinggi sampai terndah. LC1 adalah butir pertanyaan tertinggi dengan persentase sebesar $24 \%$ yang memiliki pertanyaan berupa memiliki control keuangan terhadap pengeluaran yang terjadi saat ini, banyak pelaku usaha yang menjawab skor 4 yaitu setuju sebesar $50 \%$, yang berarti pelaku usaha lebih banyak menjalani usahanya dengan kepercayaan diri dan memiliki control pengeluaran saat ini. LC3 memiliki persentase sebesar 19\% yang memiliki pertanyaan yaitu pelaku usaha dapat melakukan control keuangan karena ada pihak orang lain yang membantu dan jawaban yang paling banyak diberikan oleh pelaku usaha adalah skor 3 yang berarti bahwa pelaku usaha memiliki locus of control exsternal yang netral menganggap yang memiliki control keuangan adalah dirinya tapi melibatkan banyak pihak. Rata-rata indeks yang dihasilkan untuk locus of control adalah $22 \%$ yang berarti interpretasi dan deskripsi variabel locus of control adalah tinggi.

d. Analisis Indeks Jawaban Responden Terhadap Variabel Perilaku Keuangan

Berdasarkan tabel 6 rata-rata skor tertinggii adalah skor 4 memiliki persentase sebesar $36 \%$ berarti para pelaku usaha memiliki perilaku keuangan yang baik dengan menjawab setuju dengan indikator yaitu perencanaan keuangan, penganggaran keuangan, pengelolaan keuangan, dan penyimpanan keuangan. Skor 5 memiliki persentase $28 \%$ yang berarti para pelaku usaha yang menjawab sangat setuju ,para pelaku usaha yang menjawab skor 5 memiliki perilaku keuangan yang sangat baik. Skor 3 memiliki persentase sebesar $26 \%$ yang berarti bahwa para pelaku usaha masih banyak yang menjawab netral. Skor 2 memiliki persentase sebesar $6 \%$ yang berarti para pelaku usaha banyak menjawab tidak setuju untuk perencanaan keuangan, penganggaran keuangan, pengelolaan keuangan, dan penyimpanan keuangan. skor 1 yaitu sebesar $4 \%$ yaitu skor sangat tidak setuju, yang berarti masih banyak pelaku usaha yang menjawab pertanyaan dari variabel perilaku keuangan dengan skor satu dimana indikator dari variabel tersebut 
Financial Behavior and Small Medium Enterprises adalah perencanaan keuangan, penganggaran keuangan, pengelolaan keuangan, dan penyimpanan keuangan yang memberi kesimpulan bahwa perilaku keuangan para pelaku usaha masih rendah.

Tabel 6. Hasil Jawaban Responden Terhadap Variabel Perilaku Keuangan

\begin{tabular}{cccccccccccc} 
Perilaku Keuangan (Y) & \multicolumn{1}{c}{} & \multicolumn{1}{c}{2} & \multicolumn{1}{c}{3} & \multicolumn{7}{c}{5} \\
& $\mathrm{~F}$ & $\%$ & $\mathrm{~F}$ & $\%$ & $\mathrm{~F}$ & $\%$ & $\mathrm{~F}$ & $\%$ & $\mathrm{~F}$ & $\%$ & Indeks \\
PK1 & 1 & 3 & 1 & 3 & 6 & 20 & 11 & 37 & 11 & 37 & 24 \\
PK3 & 0 & 0 & 0 & 0 & 8 & 27 & 20 & 67 & 2 & 7 & 23 \\
PK4 & 0 & 0 & 1 & 3 & 10 & 33 & 4 & 13 & 15 & 50 & 25 \\
PK5 & 4 & 13 & 3 & 10 & 5 & 17 & 10 & 33 & 8 & 27 & 21 \\
PK6 & 3 & 10 & 4 & 13 & 9 & 30 & 9 & 30 & 5 & 17 & 20 \\
PK8 & 0 & 0 & 2 & 7 & 9 & 30 & 10 & 33 & 9 & 30 & 23 \\
Rata-Rata Total Indeks & 1 & 4 & 2 & 6 & 8 & 26 & 11 & 36 & 8 & 28 & 23
\end{tabular}

\section{Sumber : Data diolah}

Berdasarkan tabel diatas untuk variabel perilaku keuangan yang memiliki 6 butir pertanyaan memiliki nilai tertiinggi daan nilai terendah. Nilai tertinggi dalam variabel ini terrdapat padda butir PK4 yaitu 25\% dimana pernyataannya apakah para pelaku usaha mendahulukan kebutuhan paling utama terlebih dahulu dalam anggaran belanja, jawaban yang paling banyak diberikan oleh pelaku usaha adalah skor 5 atau sangat setuju yaitu sebesar $50 \%$, yang berarti para pelaku usaha selalu mendahulukan kebutuhan utama dalam anggaran belanja. PK6 memiliki persentase sebesar 20\% dimana butir pertanyaan yang diajukan adalah apakah para pelaku usaha mengajarkan pengelolaan keuangan kepada karyawan secara bertahap, jawaban yang paling banyak diberikan oleh pelaku usaha adalah skor 4 dan 3 atau cukup setuju dan setuju sebesar 30\% yang berarti banyak pelaku usaha yang mengajarkan pengelolaan keuangan kepada karyawan secara bertahap. Nilai rata-rata indeks pada variabel perilaku keuangan adalah $23 \%$ yang termasuk ke dalam kategori tinggi yang berarti interpretasi responden terhadap variabel perilaku keuangan tinggi.

\section{Analisis Data dan Uji Hipotesis \\ Model Pengukuran (Outer Model)}

Berdasarkan diagram jalur pada gambar 3, setiap instrumen pernyataan literasi keuangan, sikap keuangan, locus of control dan perilaku keuangan memiliki nilai $>0,5$ sehingga semua instrument valid,

Uji Validitas Diskriminan

Tabel 7. Average Variance Extracted (AVE)

$\begin{array}{ll}\text { Literasi Keuangan } & 0,511 \\ \text { Sikap Keuangan } & 0,579 \\ \text { Locus of Control } & 0,598 \\ \text { Perilaku Keuangan } & 0,548\end{array}$

Sumber : Hasil output smart PLS 3.0

Nilai AVE >0,50 maka sudah dikatakan valid. Pada tabel 7. di atas menunjukkan hasil nilai terendah AVE sebesar 0,511 tedapat pada variabel literasi keuangan dan nilai AVE tertinggi sebesar 0,598 yang terdapat pada variabel sikap keuangan. Dari hasil tersebut dapat diambil kesimpulan bahwa instrument dari indikator tentang variabel literasi keuangann, sikap keuangan, locus of control, dan perilaku keuangan adalah valid. 


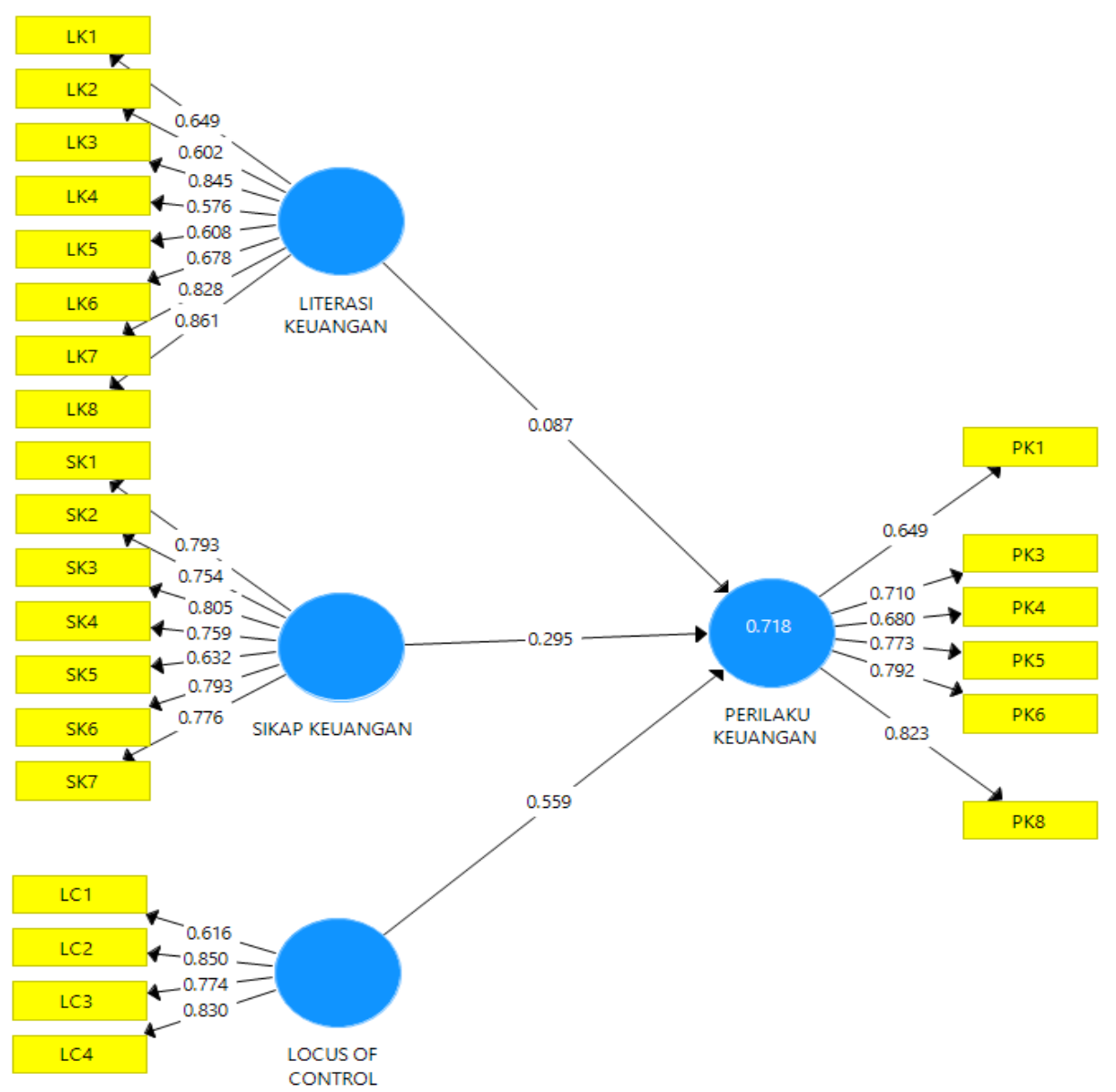

Financial Behavior and Small Medium Enterprises

Sumber : Hasil Output Smart PLS 3.0

\title{
Uji Reliabilitas PLS
}

\author{
Gambar 3. Nilai Loading FactorOuter Model
}

Tabel 8. Composite Reliability dan Cronbach's Alpha

\begin{tabular}{lcc}
\hline \multicolumn{1}{c}{ Variabel } & Composite Reability & Cronbach's Alpha \\
\hline Literasi Keuangan & 0.891 & 0.861 \\
Sikap Keuangan & 0.905 & 0.878 \\
Locus of Control & 0.854 & 0.773 \\
Perilaku Keuangan & 0.879 & 0.833 \\
\hline
\end{tabular}

Sumber : Hasil output smart PLS 3.0

Uji reliabilitas yang dilakukan dengan composite reliability dan Cronbach's Alpha menghasilkan variabel yang reliabilitas, karena nilai dari setiap variabel melebihi $>0,7$ yang artinya jawaban yang diberikan responden terhadap setiap butir pertanyaan adalah konsisten dan stabil sehingga menghasilkan nilai reliabilitas yang baik.

\section{R-Square}

Tabel 9. Nila Koefisien Determinasai

\begin{tabular}{ccc}
\hline Variabel & R-Square & R-Square Adjusted \\
\hline Perilaku Keuangan & 0.718 & 0.685 \\
\hline Sumber: Hasil output smartPLS 3.0 &
\end{tabular}

Berdasarkan tabel 9 di atas, dapat diketahui bahwa besarnya nilai R-Square $\left(\mathrm{R}^{2}\right)$ perilaku keuangan adalah sebesar 0,718. Dengan demikian dapat dikatakan kontribusi literasi keuangan, sikap keuangan dan locus of control terhadap perilaku keuangan adalah sebesar $71,8 \%$ dan sisanya sebesar $29,2 \%$ dijelaskan oleh variabel lain seperti pengetahuan keuangan, pendapatan ,kepribadian dan lainnya.

\section{Uji Hipotesis dan Uji T-Statistik}

Berdasarkan tabel 10 terlihat pada kolom Original Sample(O)di atas terlihat pada kolom Original Sample $(\mathrm{O})$ bahwa hasil nilai koefisien analisis jalur, dapat disimpulkan 
Financial Behavior and Small Medium Enterprises

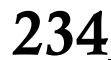

pengujian antar variabel literasi keuangan terhadap perilaku keuangan menunjukan hasil sebesar 0,087 dan sikap keuangan terhadap perilaku keuangan menunjukan hasil sebesar 0,295 serta locus of control terhadap perilaku keuangan menunjukan hasil sebesar 0,559. Maka dapat disimpulkan bahwa variabel literasi keuangan, sikap keuangan dan locus of control memerlihatkan pengaruh positif terhadap variabel perilaku keuangan artinya literasi keuangan, sikap keuangan, locus of control yang dimiliki pelaku UMKM semakin meningkat.

Tabel 10. Hasil Nilai Koefisien Analisis Jalur

$\begin{array}{lccccc}\text { Konstruk } & \begin{array}{c}\text { Original } \\ \text { Sample } \\ (\mathrm{O})\end{array} & \begin{array}{c}\text { Sample } \\ \text { Mean } \\ (\mathrm{M})\end{array} & \begin{array}{c}\text { Standard } \\ \text { Deviation } \\ (\mathrm{STDEV})\end{array} & \begin{array}{c}\text { T Statistic } \\ (|\mathrm{O} / \mathrm{STDEV}|)\end{array} & \begin{array}{c}\mathrm{P} \\ \text { Values }\end{array} \\ \begin{array}{l}\text { Keuangan -> } \\ \text { Keuangan }\end{array} & 0,087 & 0,090 & 0,163 & 0,534 & 0,593 \\ \begin{array}{l}\text { euangan -> Perilaku } \\ \text { an Control -> }\end{array} & 0,295 & 0,320 & 0,136 & 2,169 & 0,031 \\ & \mathbf{0 , 5 5 9} & \mathbf{0 , 5 6 6} & \mathbf{0 , 1 0 4} & \mathbf{5 , 3 8 8} & \mathbf{0 , 0 0 0}\end{array}$

\section{Literasi Keuangan -> \\ Perilaku Keuangan \\ Keuangan \\ Locus of Control -> Perilaku Keuangan}

Sikap Keuangan $->$ Perilaku
Sumber : Hasil output smartPLS 3.0

Uji t atau uji parsial digunakan dalam penelitian untuk mengetahui ada atau tidaknya pengaruh signifikansi antara literasi keuangan, sikap keuangan dan locus of controlterhadap perilaku keuangan. Nilai t tabel $=1,705$ yang diperoleh dari rumus $\mathrm{df}=$ $\mathrm{n}-\mathrm{k}$ atau $\mathrm{df}=30-4=26$, kemudian dihubungkan dengan derajat kepercayaan $5 \%$ atau 0,05. Berdasarkan tabel 10 diatas dapat dilihat bahwa hasil dari Hasil pengujian variabel literasi keuangan terhadap perilaku keuangan menunjukan nilai thitung $0,534<$ ttabel 1,705 dan nilai Signifikan sebesar 0,593 > 0,05 ini menunjukan bahwa literasi keuangan tidak berpengaruh dan tidak signifikan terhadap perilaku keuangan. Selain itu, hasil pengujian variabel sikap keuangan terhadap perilaku keuangan menunjukan nilai thitung 2,169 > ttabel 1,705 dan nilai Signifikan sebesar 0,031<0,05 ini menunjukan bahwa sikap keuangan berpengaruh secara signifikan terhadap perilaku keuangan. Dan hasil pengujian variabel locus of control terhadap perilaku keuangan menunjukan nilai" thitung 5,388 $>$ ttabel 1,705 dan nilai Signifikan sebesar $0,000<0,05$ ini menunjukan bahwa locus of control berpengaruh secara signifikan terhadap perilaku keuangan.

\section{PEMBAHASAN}

\section{Pengaruh Literasi Keuangan Terhadap Perilaku Keuangan}

Berdasarkan hasil penelitian pengujian hipotesis menunjukan literasi keuangan berpengaruh positif terhadap perilaku keuangan. Hal tersebut ditunjukan dengan nilai original sample sebesar 0,087 sedangkan nilai $t_{\text {hitung }} 0,534<t_{\text {tabel }} 1,705$, nilai signifikan sebesar 0,539 $>0,05$ yang berarti tidak berpengaruh literasi keuangan terhadap perilaku keuangan pada pelaku Usaha Mikro, Kecil dan Menengah (UMKM) di Kelurahan Cinere, Depok. Dapat diartikan pula bahwa dalam indikator-indikator literasi keuangan seperti pengetahuan keuangan dasar, pengelolaan kredit, pengelolaan tabungan dan investasi, manajemen risiko tidak dapat mempengaruhi perilaku keuangan. UMKM di Desa Kelurahan Cinere. Literasi keuangan para pelaku UMKM di Kelurahan Cineremasih rendah, hal tersebut terjadi karena literasi keuangan para pelaku UMKM di Kelurahan Cinere masih rendah tingkat pendidikanformal yang dimiliki lebih banyak pada tingkat SMP dan SMA/SMK yaitu 10\% dan 60\% dibandingkan dengan tingkat Pendidikan tinggi sarjana/pasca sarjana yang hanya sebesar $23 \%$, itu menjadi salah satu penyebab tingkat literasi keuangannya masih rendah. Selain itu, masih kurangnya sosialisasi yang diberikan oleh dinas UMKM kepada para pelaku UMKM mengenai pembuatan laporan keuangan dan cara mengatur keuangan usaha dengan baik. Pengetahuan yang minim bukan hanya tentang laporan keuanan atau rasio keuangan, tetapi mengenai tabungan, kredit dan investasi juga masih minim. Pengetahuan yang minim mempengaruhi perilaku keuangan para pelaku UMKM di Desa Kelurahan Cinere. Sehingga banyak dari pelaku UMKM yang tidak mencatat perencanaan dalam 
menggunakan uang, tidak memisahkan keuangan pribadi dan usaha serta tidak menggunakan kredit untuk mengembangkan usaha.

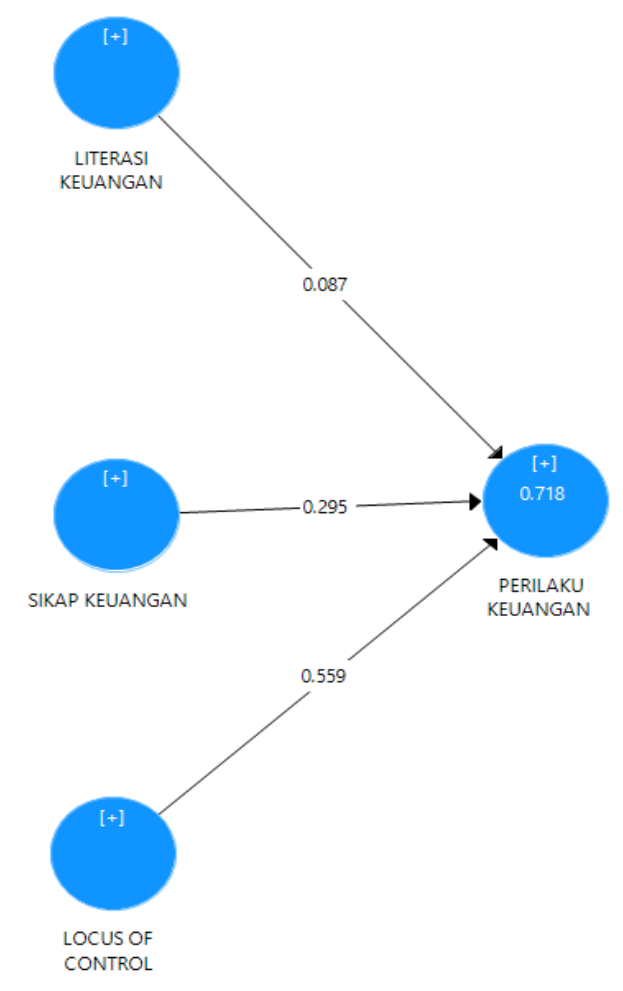

Financial Behavior and Small Medium Enterprises

Sumber : Hasil output smartPLS 3.0

Gambar 4. Inner Model

Penelitian ini sejalan dengan Nababan (2012), Kholifah Iramani (2013), Herdjiono dan Damanik (2016), yang dalam penelitiannya menyimpulkan bahwa variabel literasi keuangan tidak berpengaruh terhadap perilaku keuangan. Tetapi berbanding terbalik dengan Hamdani (2018), Susanti (2017), serta Sari (2015) yang dalam penelitiannya menyimpulkan bahwa variabel literasi keuangan memiliki pengaruh signifikan terhadap perilaku keuangan.Maka hasil penelitian ini tidak sesuai dengan hipotesis awal yang telah dibuat yaitu literasi keuangan berpengaruh secara signifikan terhadap perilaku keuangan pada pelaku UMKM Kelurahan Cinere yang artinya H1 ditolak.

Pengaruh Sikap Keuangan Terhadap Perilaku Keuangan

Berdasarkan hasil penelitian pengujian hipotesis menunjukan sikap keuangan berpengaruh positif terhadap perilaku keuangan. Hal tersebut ditunjukan dengan nilai $\mathrm{t}_{\text {hitung }} 2,169>\mathrm{t}_{\text {tabel }} 1,705$ dan nilai signifikan sebesar $0,031<0,05$ dan nilai original sample sebesar 0,295 yang berarti terdapat pengaruh sikap keuangan terhadap perilaku keuangan pada pelaku Usaha Mikro, Kecil dan Menengah (UMKM) di Kelurahan Cinere. Dapat diartikan bahwa dalam indikator-indikator sikap keuangan seperti orientasi terhadap keuangan pribadi, filsafat utang, keamanan uang dan menilai keuangan pribadi dapat mempengaruhi perilaku keuangan UMKM di Kelurahan Cinere. sesuai dengan pembahasan diatas dimana para pelaku UMKM lebih banyak yang memiliki keyakinan dalam menyikapi keuangan usahanya karena sikap keuangan yang baik akan membuat usaha baru menjadi lebih baik atau mengembangkan usahanya, sehingga perilaku keuangannya tinggi.

Penelitian ini sejalan dengan Tifani Enno Pradiningtyas (2019), Amanah (2016), Humaira (2018) yang dalam penelitiannya menyimpulkan bahwa variabel sikap keuangan memiliki berpengaruh terhadap perilaku keuangan. Maka hasil penelitian ini sesuai dengan hipotesis yang telah dibuat yaitu sikap keuangan berpengaruh terhadap perilaku keuangan pada pelaku UMKM Kelurahan Cinere yang artinya H2 diterima. 
Financial Behavior and Small Medium Enterprises

\section{Pengaruh Locus of Control Terhadap Perilaku Keuangan}

Berdasarkan hasil penelitian pengujian hipotesis menunjukan locus of control berpengaruh positif terhadap perilaku keuangan. Hal tersebut ditunjukan dengan nilai $t_{\text {hitung }} 5,338>t_{\text {tabel }} 1,705$ dan nilai signifikan sebesar $0,000<0,05$ serta nilai original sample sebesar 0,559 yang berarti terdapat pengaruh locus of control terhadap perilaku keuangan pada pelaku Usaha Mikro, Kecil dan Menengah (UMKM) di Kelurahan Cinere. Dapat diartikan pula bahwa dalam indikator-indikator locus of control seperti internal locus of control dan eksternal locus of control dapat mempengaruhi perilaku keuangan UMKM di Kelurahan Cinere. Para pelaku UMKM Kelurahan Cinere memiliki locus of control cukup tinggi karena banyak para pelaku usaha yang memiliki locus of control internal yang dapat diartikan tinggi dan bisa membuat keputusan sendiri dan tidak terlalu bergantung kepada orang lain.

Penelitian ini sejalan dengan Nur laili (2018) dan Yusnia (2017) yang dalam penelitiannya menyimpulkan bahwa variabel locus of control memiliki pengaruh terhadap perilaku keuangan. Maka hasil penelitian ini sesuai dengan hipotesis yang telah dibuat yaitu locus of control berpengaruh terhadap perilaku keuangan pada pelaku UMKM Kelurahan Cinere artinya H3 diterima.

\section{PENUTUP}

Berdasarkan analisis data dan pembahasan yang telah dilakukan dengan menggunakan Partial Least Square (PLS) mengenai perilaku keuangan pelaku Usaha Mikro Kecil dan Menengah (UMKM), hasil penelitiannya adalah sebagai berikut :

a. Variabel literasi keuangan tidak berpengaruh terhadap perilaku keuangan. Artinya, indikator indikator literasi keuangan yaitu pengetahuan keuangan dasar, pengelolaan kredit, pengelolaan tabungan dan investasi, manajemen risiko tidak berpengaruh terhadap perilaku keuangan.

b. Variabel sikap keuangan berpengaruh terhadap perilaku keuangan. Semakin tinggi indikator sikap keuangan yaitu orientasi terhadap keuangan pribadi, filsafat utang, keamanan uang dan menilai keuangan pribadi seorang pelaku usaha maka semakin baik pula perilaku keuangan pelaku UMKM Kelurahan Cinere.

c. variabel locus of control berpengaruh terhadap perilaku keuangan. Dapat diinterpretasikan bahwa semakin tinggi indikator locus of control yaitu internal locus of control dan eksternal locus of control maka semakin baik pula perilaku keuangan pelaku UMKM Kelurahan Cinere.

\section{DAFTAR PUSTAKA}

[1] Amanah, E., Iradianty, A., \& Rahardian, D. (2016). Pengaruh Financial Knowledge , Financial Attitude Dan External Locus of Control Terhadap Personal Financial Management Behavior Pada Mahasiswa S1 Universitas Telkom the Influence of Financial Knowledge, Financial Attitude and External Locus of Control on. EProceeding of Management, 3(2), 1228-1235.

[2] Anggraeni, B. D. (2016). Pengaruh Tingkat Literasi Keuangan Pemilik Usaha Terhadap Pengeloaan Keuangan. Studi Kasus: Umkm Depok. Jurnal Vokasi Indonesia, 4(1).

[3] Ferdinand, Augusty. (2014). Metode Penelitian Manajemen, Semarang:BP Universitas Diponegoro.

[4] Herdjiono, I., \& Damanik, L. A. (2016). Pengaruh Financial Attitude,Financial Knowledge, Parental Income Terhadap Financial Management Behavior. Jurnal Manajemen Teori Dan Terapan | Journal of Theory and Applied Management, 9(3), 226241. https://doi.org/10.20473/jmtt.v9i3.3077

[5] Humaira, I., \& Sagoro, E. M. (2018). Pengaruh Pengetahuan Keuangan, Sikap Keuangan, Dan Kepribadian Terhadap Perilaku Manajemen Keuangan Pada Pelaku Umkm Sentra Kerajinan Batik Kabupaten Bantul. Nominal, Barometer Riset Akuntansi Dan Manajemen, 7(1). https://doi.org/10.21831/nominal.v7i1.19363 
[6] Iriyadi, I., Maulana, M.A. and Nurjanah, Y., 2018, December. Financial Reporting for Micro Small and Medium Enterprises Towards Industrial Revolution Era 4.0. In International Conference On Accounting And Management Science 2018 (pp. 32-38).

[7] Kholilah, N. Al, \& Iramani, R. (2013). Studi Financial Management Behavior Pada Masyarakat Surabaya. Journal of Business and Banking, 3(1), 69-80.

[8] Ling, T.S. and Pratomo, A.W., 2020. Pengaruh Brand Image, Persepsi Harga dan Word Of Mouth Terhadap Keputusan Pembelian Konsumen The Highland Park Resort Hotel Bogor. Jurnal Ilmiah Pariwisata Kesatuan, 1(1), pp.31-42.

[9] Lianto, R., \& Elizabeth, S. M. (2017). Rizky Lianto, Sri Megawati Elizabeth. 1-12.

[10] Mulyana, M., Rainanto, B.H., Astrini, D. and Puspitasari,

[11] R., 2020. Persepsi Mahasiswa Atas Penggunaan Aplikasi Perkuliahan Daring Saat Wabah Covid-19. JAS-PT (Jurnal Analisis Sistem Pendidikan Tinggi Indonesia), 4(1), pp.47-56.

[12] Muanas, M. and Mulia, I., 2020. Pendampingan Penguasaan Akuntansi Dasar Bagi Pegawai BPR Mitra Daya Mandiri Bogor. Jurnal Abdimas Dedikasi Kesatuan, 1(1), pp.51-56.

[13] Soleh, M., Sutarti, S. and Rosita, S.I., 2020, May. The Effect of Human Resources Quality and Technology Adoption on the Quality of Financial Reporting (Evidence from MSMEs in Bogor). In 2nd International Seminar on Business, Economics, Social Science and Technology (ISBEST 2019) (pp. 199-203). Atlantis Press.

[14] Nababan, D., \& Sadalia, I. (2012). Analisis Personal Financial Literacy dan Financial Behaviour Mahasiswa Strata 1 Fakultas Ekonomi Universitas Sumatera Utara. Media

[15] Pamungkas, B., Flassy, D.A., Yudanto, S., Rachman, H.A., Rahayu, S., Komarudin, S. and Setijono, H., 2018. Accrual-based accounting implementation in Indonesian's local governments compared to other countries' experiences. Man in India, 98(1), pp.1-23.

[16] Pradiningtyas, T. E., \& Lukiastuti, F. (2019). Pengaruh Pengetahuan Keuangan dan Sikap Keuangan terhadap Locus of Control dan Perilaku Pengelolaan Keuangan Mahasiswa Ekonomi. Jurnal Minds: Manajemen Ide Dan Inspirasi, 6(1), 96. https://doi.org/10.24252/minds.v6i1.9274

[17] Qoribudin, M. and Sukartaatmadja, I., 2018. Analysis of The Effects of Trade Receivable Policies, Funding Policies and Investment Policies on Company Profitability Case Study on PT. Astra International, Tbk, PT. Astra Otoparts, Tbk, And PT. Gajah Tunggal, Tbk. In THE INTERNATIONAL CONFERENCE ON ACCOUNTING AND MANAGEMENT SCIENCE (p. 260).

[18] Roestanto, A. (2017). Literasi Keuangan. Yogyakarta: ISTANA MEDIA.

[19] Roestiono, H., 2019. Pengaruh Verifikasi Data Nasabah Kredit UMKM dan Nilai yang Diberikan untuk Menghindari Kredit Bermasalah. Jurnal Ilmiah Manajemen Kesatuan, 7(2), pp.232-240.

[20] Rosita, S.I., Pramiudi, U. and Efrianti, D., 2017. Pelatihan Akuntansi Bagi Umkm Untuk Meningkatkan Kinerja Keuangan Perusahaan. Jurnal Abdimas, 1(1), pp.13-15.

[21] Sari, D. A. (2015). Financial Literacy dan Perilaku Keuangan Mahasiswa. Buletin Bisnis \& Manajemen, 01(02), 171-189.

[22] Sari, Ratna Candra. (2018). Akuntansi Keprilakuan Teori dan Implikasi. Yogyakarta : C.V Andi Offset

[23] Setiawan, B. and Fadillah, A., 2020. Pendampingan Penerapan Strategi Promosi Berbasis Digital Bagi UMKM Di Wilayah Kota Bogor. Jurnal Abdimas Dedikasi Kesatuan, 1(1), pp.29-36.

[24] Sudradjat, S. and Djanegara, M.S., 2020. PKM Uji Kompetensi Bidang Keahlian Akuntansi Di SMK Bina Sejahtera Kota Bogor. Jurnal Abdimas Dedikasi Kesatuan, 1(1), pp.21-28.

[25] Sugiyono. (2016). Metode Penelitian Kuantitatif Kualitataif dan Kombinasi (Mixed Methods). Bandung: Alfabeta.
Financial Behavior and Small Medium Enterprises 
Financial Behavior and Small Medium Enterprises
[26] Susanti, A. (2017). Tingkat Pendidikan, Literasi Keuangan, Dan. Telaah Bisnis, $18(1), 45-56$.

[27] Tantowi, A.I. and Pratomo, A.W., 2020. Pengaruh Store Atmosphere dan Experiential Marketing Terhadap Keputusan Pembelian Di Kopi Daong Pancawati. Jurnal Ilmiah Manajemen Kesatuan, 8(2), pp.65-78.

[28] Yusnia, \& Jubaedah. (2017). Pengaruh Pendapatan, Lokus Pengendalian Dan Pengetahuan Keuangan Terhadap Perilaku Keuangan Pelaku UMKM Kecamatan Cinere. Jurnal Ekonomi Dan Bisnis, 4(2), 173-196. 